\title{
Anthropogenic Drivers of the Pressures on the Ramsar Site of Sakumo Lagoon in Ghana
}

\author{
Divine Odame Appiah, Deborah Yankson
}

\author{
Department of Geography and Rural Development, Faculty of Social Sciences College of Art and Social Sciences, \\ Kwame Nkrumah University of Science and Technology, Kumasi, Ghana. \\ Email:doappiah.cass@knust.edu.gh
}

\begin{abstract}
This paper examines the range of human pressures on the Sakumo Lagoon. These pressures have contributed to the current state of the lagoon. The wetlands around the Ramsar site of the Sakumo Lagoon are suffering from unsustainable fishing, farming, deliberate bush burning, improper domestic solid and industrial effluents disposal as well as unregulated tourism and recreation activities. The various anthropogenic drivers-responses were examined through the 'driver-pressurestate-impact-response' (DPSIR) framework. The framework involved empirical field data collection, laboratory test and analysis of eight water quality parameters such as $\mathrm{pH}$, turbidity, conductivity, total suspended solids (tss), biological oxygen demand (BOD), nitrates and ammonia. Results showed that over-exploitation of natural resources and pollution due to inappropriate agricultural and waste management practices are responsible for the wetland degradation. Institutional measures should be strengthened to curb the degradation of the Sakumo wetland.
\end{abstract}

Keywords: Pollution pressures; Anthropogenic drivers-responses; Wetland socio-economic activities

\section{Introduction}

Until recently, wetlands were virtually considered as 'waste lands' or areas that only served as breeding grounds for mosquitoes. However, since 1971, when the convention on Wetlands of International Importance (Ramsar Convention, 1971) came into force, wetlands have been internationally recognized as ecosystems of considerable importance, comparable to our forest, rangelands and marine ecosystems.

The Ramsar Convention describes wetlands as "areas of marsh, fen, peat land or water, whether natural or artificial, permanent or temporal, with water that is static or flowing, fresh, brackish or salt including areas of marine water, the depth of which at low tide, does not exceed six meters (Ramsar Convention, 1971). The Sakumo lagoon, one of five coastal wetlands in Ghana, recognized under the Ramsar Convention because of their importance for a number of migratory shorebirds, is rated for their potentials for tourism and recreational value around the coast of Ghana (Agyepong et al., 1999; Ministry of Lands and Forestry, 1999).
Apart from the ecological functions of wetlands, they are also of great economic importance to the local communities due to high biological diversity and cultural value (Gordon et al., 1992). Among the various uses of coastal wetlands to human communities, are the provisions of nutrient-rich habitats for fish breeding, food or commercial products such as shells, salt, thatch, and wood that constitute the major sources of livelihood and socio-economic well-being of the local inhabitants (Ntiamoah-Baidu, 1991). Analysis of water qualities show that Dissolved Oxygen (DO) is essential for the maintenance of healthy lagoons, lakes and rivers. The lack of oxygen in a water body is a signal of severe pollution (Holmbeck-Pelham et al., 2005). Biological Oxygen Demand (BOD) measures the oxygen a bacteria will consume while decomposing organic matter under aerobic conditions.

The BOD therefore characterizes the amount of oxygen quantifiably spent for biological processes. Water qualities with high BOD levels indicates that most of the available DO is consumed by aerobic bacteria, depriving other aquatic organisms of the oxygen they need to survive. The Chemical Oxygen Demand (COD) is the amount of oxygen required to 
oxidize the organic matter by the use of dichromate in an acid solution and to convert to carbon dioxide and water (Holmbeck-Pelham et al., 2005). Since the concentration of inorganic compounds can be determined by the usual chemical analysis of water, COD serves as an indicator of total concentration of organic substances in the water.

The Sakumo wetland area however, is threatened by pollution from domestic and industrial solid and liquid waste, over-exploitation of the wetland resources and urbanization. These pressures on the wetland are due to the rapidly growing human populations and its attending drivers on the resource. For instance, the Sakumo lagoon is located in an urban area in the Greater Accra Region of Ghana, where domestic and industrial waste management is problematic (Asmah et al., 2007). In most cases, the lagoon becomes the final receptacle of both solid and liquid waste materials. Only $4.5 \%$ of the households in this region have access to adequate liquid waste disposal facilities (Ghana Statistical Services, 2002). This implies that up to $95.5 \%$ of the remaining households discharge their untreated liquid wastes onto unauthorized spaces and drain, which discharge into various water bodies via storm water drains. The Sakumo wetland receives quite a substantial proportion of these wastes.

Further, most residents dispose of their domestic waste into the surrounding environment: bush, streams, lagoons or drainage systems, (Agyepong et al., 1999). These activities threaten the ecological health of the lagoon, since contaminated urban surface runoff is known to account for most of the polluting effects observed in rivers, lakes, lagoons and other water bodies (Taebi and Droste, 2004).

The main objective of the paper is to identify the causes and effects of the various adverse human activities on the ecological integrity of the Sakumo lagoon wetland. The conceptual framework underpinning the study is the Driver-PressureStateImpact- Response (DPSIR) approach adopted by the European Environment Agency (Zacharias et al., 2008; Smeets and Weterings, 1999). The DPSIR approach is a development form of the PressureState-Response (PSR) framework developed by OECD (1993).

This framework is used to organize information about the state of the environment and the relationship between human activities and possible environmental changes. The DPSIR analysis is a valuable model, as it enables the parallel assessment of socio-economic and environmental parameters
(Walmsey, 2002; Elliot, 2002: Zacharias et al., 2008). Social and economic developments (Drivers) exert pressures on the environment and result in change in its state i.e. physical, chemical and biological features (Pirrone et al., 2005).

Furthermore, these changes lead to impact on ecosystems, human health and natural processes and this impact eventually, generate social and political responses (Smeets and Weterings, 1999). Such responses can affect any element of the DPSIR variables which can then create a feedback directly on the state of the environment or on the driving forces, hence, on human activities. The DPSIR is particularly being used for the analysis of sustainable management of the Sakumo wetlands, because in such an area the major drivers derived from anthropogenic activities (Lin et al., 2007), have harmful effects on the water body.

This theoretical framework (Figure1) is amenable to our study in order to detect and analyze the driving forces and their pressures on the Sakumo Lagoon catchment, assess their state, identify the associated impacts and eventually, propose the necessary responses in order to restore, protect and preserve the collection of these valuable habitats. The development of the DPSIR model incorporated here a profound analysis of the Sakumo Lagoon Catchment (SLC) conditions and of the local social characteristics. Thus, the drivers can be defined as the elements in the broader area of the SLC that create the pressures to the wetland, while the pressures are the causes for the habitat's status alteration (Kristensen and Alongi, 2006).

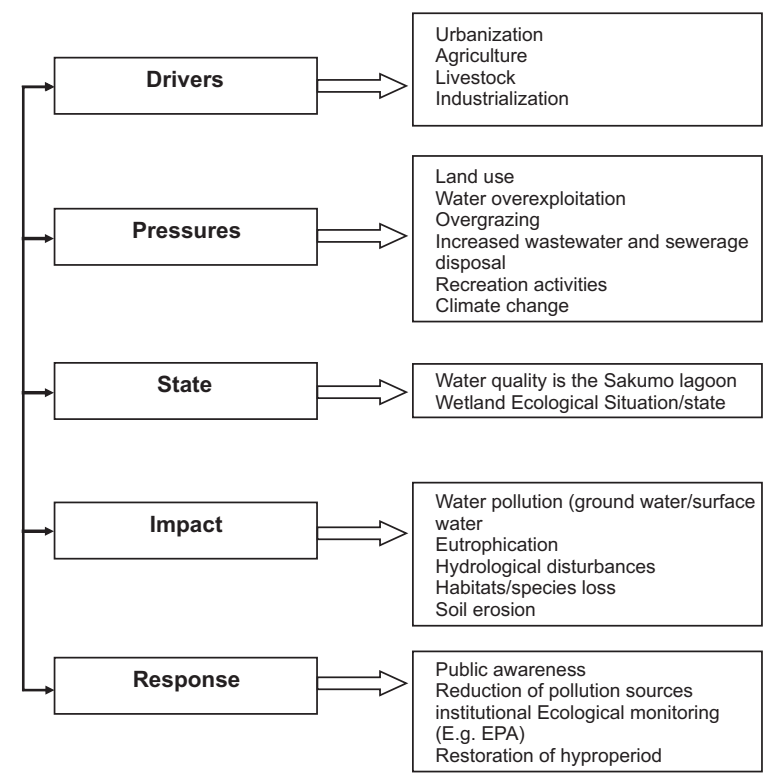

Source: Adopted and modified from Zacharias et al., 2008

Fig.1: A model of parameter interactions in the Sakumo Lagoon. 
This approach is based on the concept of causal links that start with the human activities within the Sakumo basin (driving forces) overfishing, bush burning and domestic and industrial effluents discharged in the lagoon, exerting pressures on the wetland, which then changes the quality and the quantity of natural resources and finally leads to societal responses. We utilize the DPSIR analysis (Smeets and Weterings, 1999; Pirrone et al., 2005) and use indicators (sets of physical, biological or chemicals variables) in order to provide for policy makers, clear and specific information on the sustainable management of environmental resources like the case of the Sakumo Wetland.

\section{Profile of the study site}

The Sakumo Ramsar Site $\left(05^{\circ} 30^{\prime} \mathrm{N}\right.$ and $00^{\circ} 08^{\prime}$ W) covering an area of about 1,364 hectares with a highest point of 86.9 meters and an average elevation of 45.7 meters, is located in the Greater Accra Region of Ghana and lies between the cities of Accra and Tema, approximately $3 \mathrm{~km}$ west of Tema Township. The lagoon was a typically closed lagoon, until pipes were laid under the sandbar to enable the construction of the Accra-Tema road. The lagoon is now permanently connected to the sea, and this represents a transitory stage between a closed and an open lagoon. The Sakumo Lagoon, kept open to the sea by two parallel culverts (each 70 meters long and 1.4 meters in diameter), is fed by two main streams, the Mamahuma and the Dzorwulu (Fig. 2).

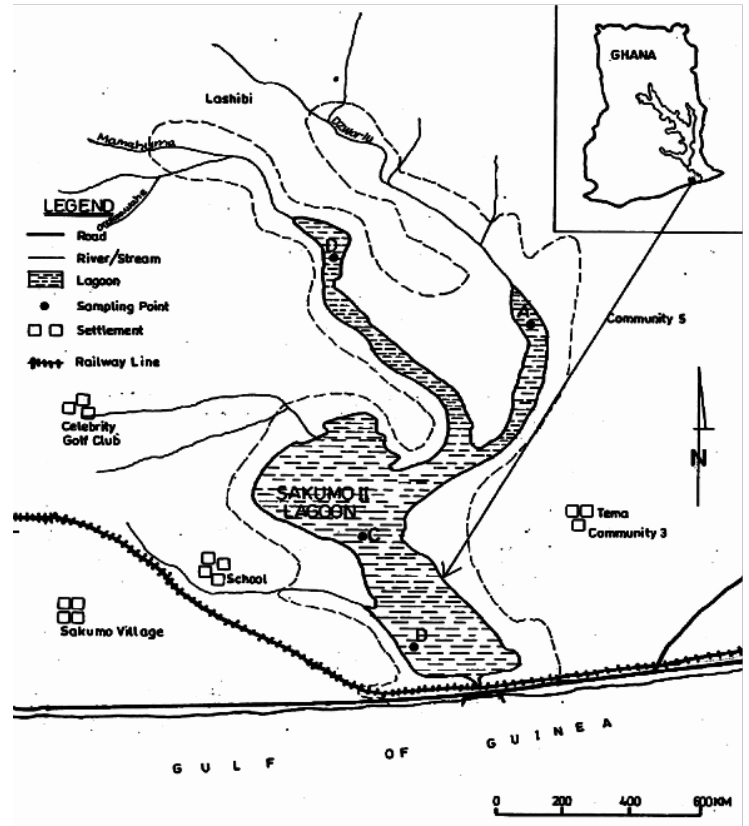

Source: Department of Geography and Rural Development, KNUST, Kumasi, Ghana

Fig. 2: A map of the Sakumo Ramsar (Lagoon) site showing the sampling points.
Both streams have been dammed upstream, to provide water for crop and livestock farming. The catchment area has limited groundwater potential because of low rainfall and the impermeability of the underlying geology, (Tumbulto and Bannerman,1995).

The Sakumo lagoon lies in a semi-arid coastal savannah zone, with two rainy seasons annually. Mean annual rainfall is about $735 \mathrm{~mm}$. The mean atmospheric temperature is about $26.7^{\circ} \mathrm{C}$ and there is little variation throughout the year. There are basically four types of soils underlying the Sakumo Catchment. These are ferric luvisols, chronic cambisols, calcic vertisols and ferric acrisols. Four habitat types exist in the Sakumo catchment: open lagoon, surrounding plains, freshwater marsh and coastal savannah grassland. The lagoon also serves as a nursery ground for some commercially important marine fish species such as Ethmalosa fimbriata, Mugil spp., Lutjanus spp. and Caranx spp., (Asmah et al., 2008). The main vegetation found in the freshwater marsh includes the succulent forb sessuvium, portulacastrum (90\%) and the grasses, imperata cylindrical and paspulum vaginatum. The reed, typha australis is associated mainly with the estuarine brackish-freshwater marsh (Atupra, 1993). These physical characteristics have different effects on the functioning and physicochemical properties of the wetland.

\section{Methodology}

Empirical studies and measurements were taken at different sections of the lagoon. The Lagoon was divided into four (4) sections and water samples were collected from Dzowurlu-Lagoon Confluence (DLC), Sea-Lagoon Estuary (SLE), Mid-Section of the Lagoon (MsL) and Mamahuma - Lagoon Confluence (MLC) sections of the Sakumo Lagoon, (referred to as sites $\mathrm{A}, \mathrm{B}, \mathrm{C}$ and $\mathrm{D}$ respectively: see Figure 2). These divisions were identified because of the different data sets required for the study, of which the best samples were expected from specific sections earmarked within the wetland basin. With each water sample, the following water quality parameters were analyzed: Dissolved Oxygen (DO), Total Suspended Solids (TSS), Total Dissolved Solids (TDS), Phosphates, Nitrates and ammonia.

Water samples for the assessments of the assessments of nutrients (Phosphates, Nitrates and ammonia), TSS and TDS were collected in pre-washed 1-liter polythene bottles. Samples for the analysis of DO were collected in $250 \mathrm{ml}$ light and dark 
glass bottles respectively. All samples were collected in the afternoon, kept on ice in an insulated ice box, and transported to the CSIR.

The TDS was determined by the gravimetric method, while the TSS was determined by membrane filtration and drying of the filter at $105^{\circ} \mathrm{C}$ followed by weighing. The DO was determined by Azide Modification of Winkler's method, nitrate, ammonia and phosphate were analyzed by the hydrazine reduction, direct nesslerisation and stannous chloride methods respectively. All methods followed the Standard Methods for the Examination of Clean Water and Waste Water, (APHA_AWWA_WEF, 1989).

Finally, photographs were taken and some interviews conducted during the fieldwork, on aspects of anthropogenic drivers arising as a result of patronage of the wetland basin for economic activities including fishing; framing, settlement expansion and tourism. This is the method used to ascertain the effects of the drivers on the ecological status of the Sakumo wetland environment.

\section{Results and discussions}

Water samples from the four designated sites for the analysis of eight water quality parameters, that is the dissolved oxygen (DO), Chemical Oxygen Demand (COD), Total Suspended Solids (TSS), total dissolved solids (TDS), Phosphates, Nitrates and Ammonia analyzed yielded different important results as summarized in Table 1. Relationships between these parameters have significant implications on the environmental conditions of the wetland.

Table 1

Summary of results on water quality parameters from the Sakumo Lagoon

\begin{tabular}{lcrrrr}
\hline $\begin{array}{l}\text { Parameters } \\
\text { (MgL-1) }\end{array}$ & $\begin{array}{c}\text { Dzorwulu-Lagoon } \\
\text { Confluence(DLC) }\end{array}$ & $\begin{array}{c}\text { Sea-Lagoon } \\
\text { Estuary(SLE) }\end{array}$ & $\begin{array}{r}\text { Midsection of } \\
\text { Lagoon(MsL) }\end{array}$ & $\begin{array}{r}\text { Mamahuma-Lagoon } \\
\text { Confluence(MLC }\end{array}$ & $\begin{array}{r}\text { EPA/WHO } \\
\text { Guidelines }\end{array}$ \\
\hline Dissolved Oxygen & 8.50 & 4.00 & 4.50 & 9.20 & 5.0 \\
Biological Oxygen Demand & 5.50 & 28.0 & 12.50 & 8.00 & 50 \\
Chemical Oxygen Demand & 107 & 121 & 181 & 79.0 & 250 \\
Total Suspended Solids & 60.0 & 118 & 198 & 44.0 & 50 \\
Total Dissolved Solids & 2,363 & 15,064 & 35,168 & 6,401 & 1,000 \\
Phosphates & 2.60 & 1.96 & 0.228 & 1.28 & 2 \\
Nitrates & 0.380 & 2.86 & 0.175 & 0.198 & 1 \\
Ammonia & 0.009 & 0.040 & $<0.001$ & $<0.001$ & 1.5 \\
\hline
\end{tabular}

Source: Authors' laboratory analysis, 2010

Dzorwulu river-Lagoon Confluence (DLC) had BOD of 5.50 mgl-1 while Mamahuma-Lagoon Confluence (MLC) had a BOD of $8.00 \mathrm{mgl}^{-1}$. These figures indicate a high $\mathrm{DO}$ in the Lagoons $\left(8.50 \mathrm{mgl}^{-1}\right.$ and $9.20 \mathrm{mgl}^{-1}$ respectively). This implies that at both sample points, there is little or no stress on the aquatic organisms (Martin, 1970). On the other hand, at Sea-Lagoon Estuary (SLE) and Midsection of Lagoon (MsL) with relatively high BOD measuring $28.0 \mathrm{mgl}^{-1}$ and $12.5 \mathrm{mgl}^{-1}$ respectively, the researcher found a corresponding low level of DO which indicates that a lot of oxygen is used up by aerobic bacteria and hence rob other aquatic organisms of the oxygen they need to sustain life.

If effluent with high BOD levels is discharged into a stream/river, it will accelerate bacterial growth in the river and consume the oxygen in the river. The oxygen may diminish to levels that are lethal for most fish and many aquatic organisms. Waters with a BOD of $<3.00 \mathrm{mgl}-1$ are known to have received no significant pollution discharges, while BOD values $>$ $8.00 \mathrm{mgl}-1$ are indicative of moderate pollution (Martin, 1970), and BOD values of $12.00 \mathrm{mgl}-1$ or more are considered grossly polluted. Based on these classifications, the Sakumo Lagoon Midsection and Sea-Lagoon estuary (28.0 mgl-1 and $12.5 \mathrm{mgl}^{-1}$ ) respectively, are categorized as grossly polluted.

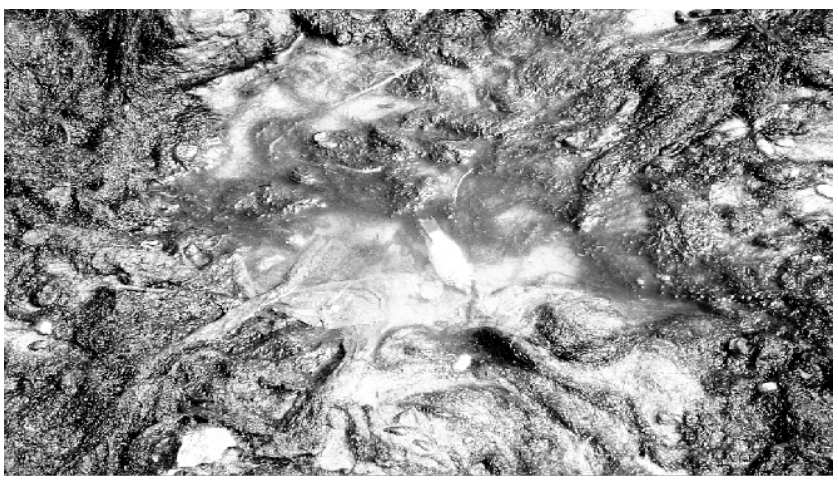

Source: Photograph taken by authors during field studies, 2010

Fig. 3: A photograph of heavy algal bloom, which has killed the fishes 
Other water quality parameters such as the total dissolve solids and the total suspended solids as well as nutrients like nitrogen, phosphorus and ammonia, showed significant levels of pollution with respect to quality. With the exception of ammonia, all other parameters recorded higher than recommended value or tolerance for non-pollution (see Table 1).

Eutrophication is usually a human-induced process in aquatic environments; where elevated nutrient levels over stimulate biological production of green algae (Fig. 3). Possible sources of phosphorus into the Sakumo Lagoon include industrial effluence discharged from beverage and plastic processing companies, found within the catchment area. Coupled with this, untreated sewage from the Tema Waste Treatment Plant and other solid waste from nearby households which are disposed-off indiscriminately, have found their way into the wetland.

Once nutrient pollution reaches the coastal zone, it stimulates harmful overgrowth of algae, which have direct toxic effects and ultimately results in low-oxygen conditions (Asmah et al., 2007). Soil erosion also contributes to phosphorous to rivers. Sources of this could be from animal waste washed in runoff into the lagoon. Phosphates levels recorded from the four sampling points (DLC, SLE, MsL and MLC) were $2.6 \mathrm{mgl}^{-1}, 1.96 \mathrm{mgl}^{-1}, 0.228 \mathrm{mgl}^{-1}$ and $1.28 \mathrm{mgl}^{-1}$ respectively. There was excessive concentrations of nutrients over stimulated aquatic plant and the algal bloom.

As a result, bacterial respiration and organic decomposition use up dissolved oxygen, depriving fish and invertebrates of available oxygen in the water. Driven blooms of toxic algae and seaweed also cause problems by reducing water clarity, making it difficult for marine animals to access food and also block the sunlight needed by the water grasses, which serve as nurseries for many important fish species. However, low levels of phosphate $\left(0.05 \mathrm{mgl}^{-1}\right)$ and nitrate-nitrogen $\left(0.18 \mathrm{mgl}^{-1}\right)$ were also reported by Biney (1995) in the immediate offshore waters of Sakumo II lagoon.

\section{Urban settlement encroachment}

The Sakumo lagoon's location in an urban area, where there is high competition for land for estate developments and industrial activities has increased the level of encroachment which adversely affects the health of the lagoon (Fig. 4).

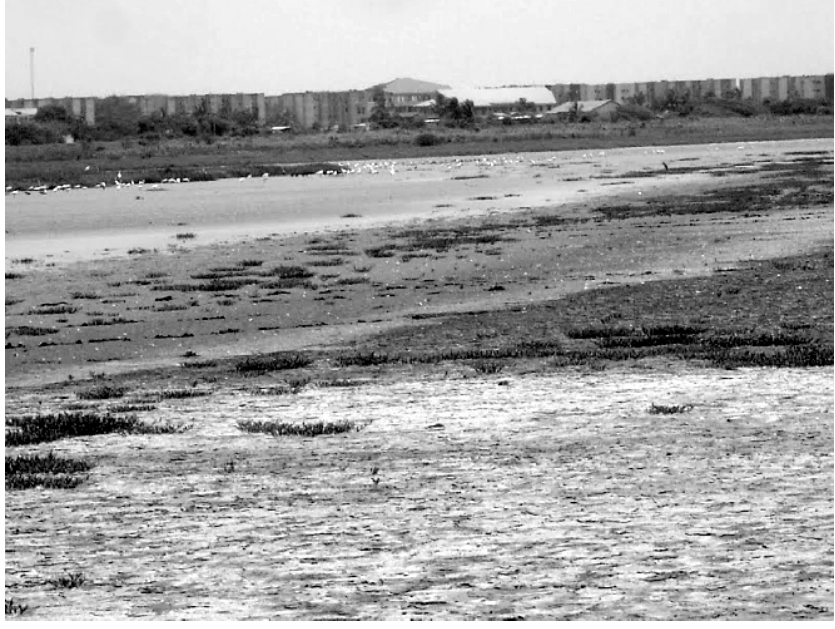

Source: Photograph taken by authors during field studies, 2010

Fig. 4: Urban residential encroachment into the lagoon catchment

As a result of the urban encroachment, most of the residents dispose off their domestic solid waste into surrounding bushes and the lagoon fringes (Agyepong et al.,1999). Also, most of the drains from the town discharge sediment-laden water into the feeder streams finally entering the lagoon.

The most common wastes recorded were plastic and metal containers. In the process of being washed down by the stream, some of the garbage gets entangled in aquatic weeds (Fig. 5), while others float on the water, obstructing the free flow of the stream water, and thereby reducing its current. Siltation ultimately sets in, causing the narrowing of the stream bed as observed in the upper zone. The long-term effect of this is the depletion of dissolved oxygen essential for the maintenance of healthy aquatic life of the lagoon. The lack of oxygen in a water body therefore is an indication of severe pollution (Holmbeck-Pelham et al., 2005).

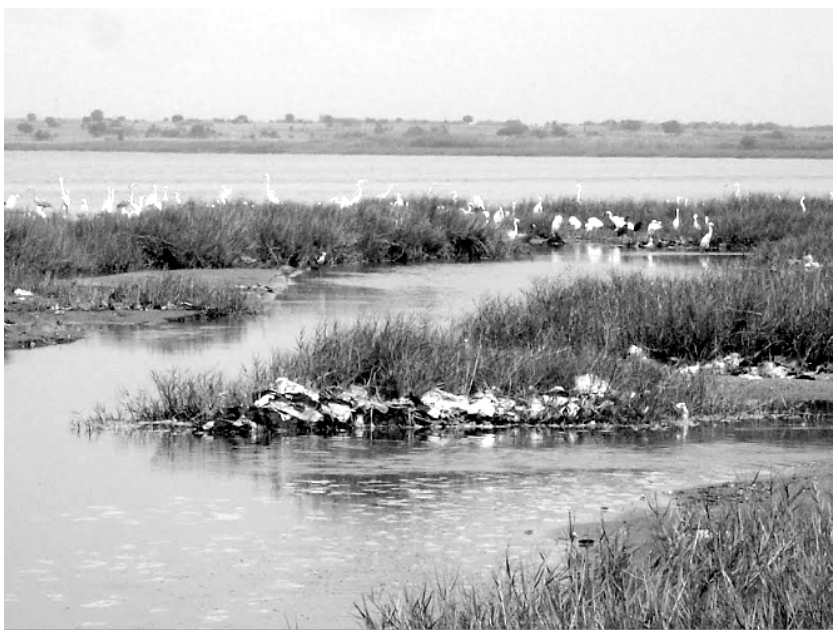

Source: Photograph taken by authors during field studies, 2010

Fig. 5: Pollution from indiscriminate solid waste disposal 
Low DO levels recorded at the Sea-Lagoon Estuary and Mid-section of Lagoon, which is $4.0 \mathrm{mgl}^{-1}$ and $4.5 \mathrm{mgl}^{-1}$, respectively are lower than the EPA/WHO tolerable limit, an implication for low oxygen for aquatic organisms. With low levels of $\mathrm{DO}$, there is a lot of stress on aquatic life including fishes, and this could result in death as evidenced by the dead fishes found at the Sea - Lagoon Estuary, a situation the EPA and Wildlife Services officials are not aware of.

\subsection{Unsustainable fishing activities}

Coastal lagoons form an integral part of marine fisheries and provide important spawning and nursery grounds for many fish species (Entsua Mensah et al., 2000). The Lagoon fisheries are the main source of livelihood to the local folks. Fishing is predominantly done by the men whilst the women either sell the fish outright or fry them for sale. Some fishermen from other towns including Lashibi and Nungua also fish in the Lagoon and usually fishing is done within the early hours of the morning.

The major fin fish species present in the lagoon were Tilapia sp. The dominant shell fish species, crabs, (callinectes sp.), were also residents in the Lagoon and are normally transported to the Lagoon by high tides. The fishes caught are usually of very small sizes (Fig. 6), probably due to over fishing or continuous fishing, using fishing nets with apertures in diameters of less than $2.5 \mathrm{~cm}$. The lack of bigger fishes was obviously an indication of overfishing, especially during the breeding season of the fish. This has the adverse effect on the wetland's natural rate of regeneration (Attuquayefio and Gbogbo, 2001; Mula-moottil et al., 1994).

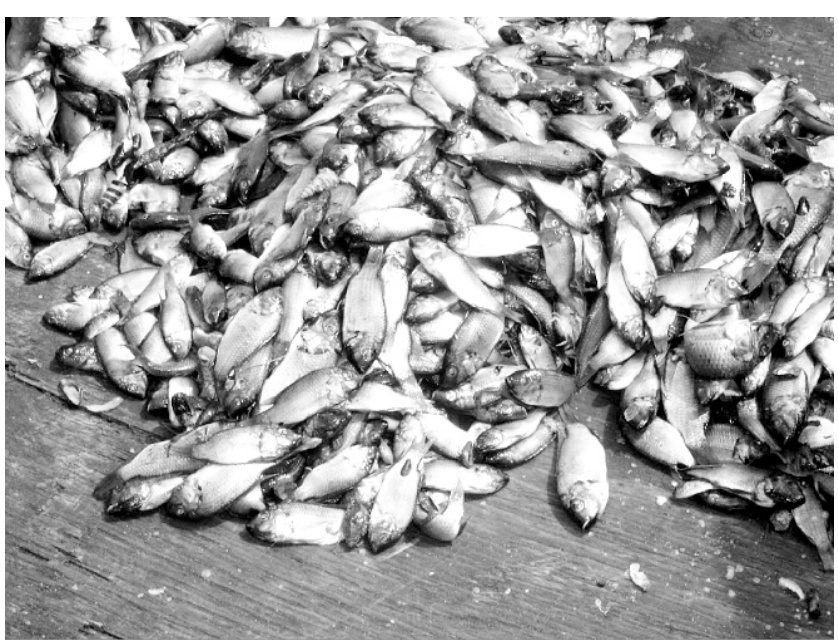

Source: Photograph taken by authors during field studies, 2010

Fig. 6: Undifferentiated fishing, a recipe for stock depletion
The fishermen appeared not to realize this and rather complained of low yields. Some of the fishermen we interacted with were conscious of the negative impact of their activities on fish stocks, but such fishermen admitted that they could not trust other colleagues to stop the practice even if they themselves stop their negative activities; a common property dilemma! This ultimately leads to the tragedy of the commons. As a result of the low yields, some of the youth have resulted to burning bushes along the Lagoon fringes to trap crabs to sell for income. This was evident by patches of burnt grasses along the banks of the lagoon; (Fig. 7). This activity of the youth, as the research gathered, is known neither to Wildlife Services nor the Environmental Protection Agency who are mandated to protect the Sakumo Ramsar Site.

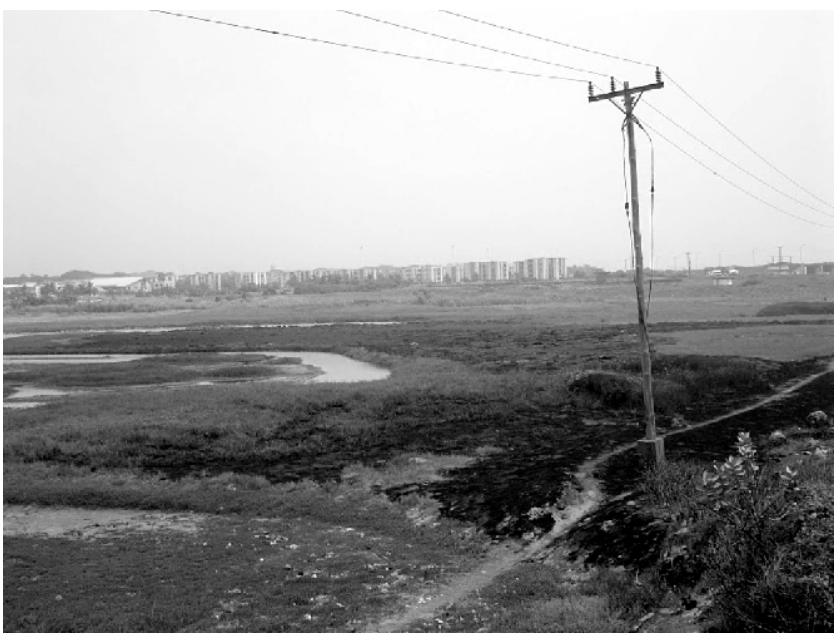

Source: Photograph taken by authors during field studies, 2010

Fig. 7: Deliberate bush burning of wetland vegetation

The deleterious effects of such human-induced bushfires on the distribution and abundance of the biodiversity on the wetland cannot be underestimated. The burning of these grasses along the banks of the lagoon will affect its effective functioning because, when it rains the ashes from the burnt grasses will be washed into the lagoon. Also, due to the burning of the grasses, the lagoon and its aquatic organisms are exposed to excessive sunlight.

\subsection{Farming activities within the catchment}

Driven by the urge for food security, most parts of the wetland catchment area have been cleared for vegetables cultivation, notably pepper, okra, cabbage, lettuce, carrots, tomatoes and cowpea and other food crops such as maize being the common crop cultivated. Farms are usually found along tributaries 
of the Dzowurlu and the Mamahuma rivers. The crops are grown on raised beds or ploughed fields to prevent flooding and erosion. The process of land clearing for cultivation destroys the vegetation, leading to desiccation and salinization of the wetland soils and destruction of the habitats of some organisms inhabiting the wetland (Kristensen,2006). The loosed exposed soil is also prone to being washed into the lagoon causing siltation.

Sediments enter the lagoon via upland soil erosion, bank erosion and urban runoff, due to weaken top soils. The TSS and TDS recorded at the various sampling sites far exceeded the standard EPA Guideline. Total Suspended Solids (TSS) values recorded were $60 \mathrm{mgl}^{-1}, 118 \mathrm{mgl}^{-1}, 198 \mathrm{mgl}^{-1}$ and $44 \mathrm{mgl}^{-1}$ at the DLC, SLE, MsL and MLC sampling sites, respectively, of the Sakumo Lagoon (Table 1). The high concentrations of TSS and TDS in the Sakumo Lagoon have resulted in the cloudy colour of the lagoon waters. Furthermore, the use of inorganic fertilizers with Nitrogen, Phosphorus and Potassium components (N-P-K), on crops, also affects the wetland water quality in the long-run as non-point sources of pollution.

The excessive supplies of such nutrients into the wetland increase the productivity of aquatic plants, which invades the water and caused reduced oxygen content for aquatic life. The resultant oxygen depletion causes unpleasant ecological conditions on the aquatic life; such as stress on fishes which eventually lead to death (Fig. 8). Human activities such as farming within the catchment area have accelerated discharge and accumulation of sediments into aquatic ecosystems leading to decline in surface water quality and health of aquatic biodiversity (Atupra, 1993). The results of sedimentation and siltation of the Sakumo Lagoon have had adverse impacts on the aquatic ecosystem.

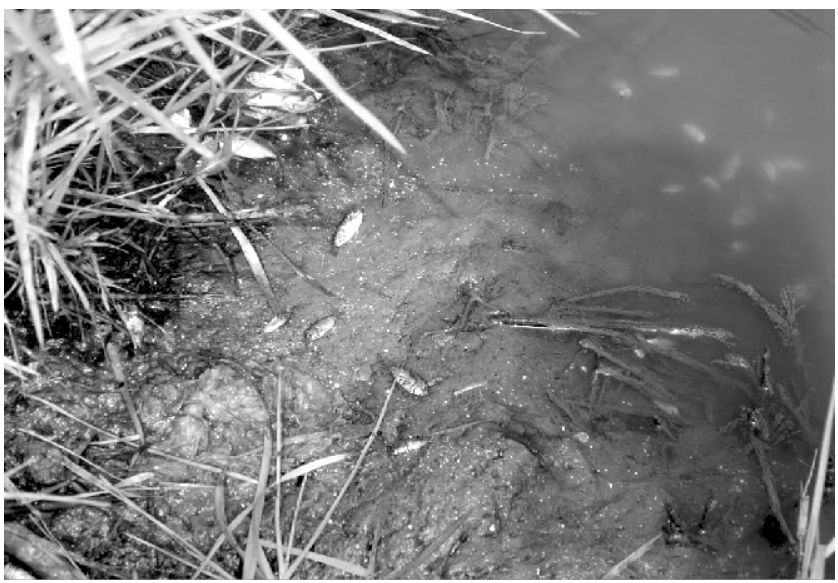

Source: Photograph taken by authors during field studies, 2010

Fig 8: Dead fishes caused by excess pollution

\section{Conclusion and recommendations}

The Sakumo Ramsar Site has over the years been subjected to intense use of its natural resources. This has resulted in degradation and pollution of the Lagoon, specifically eutrophication, sediment siltation of the lagoon, invasion of aquatic weeds, deforestation of vegetation, and reduction in the population density of the inhabiting fauna.

The range of human pressures driven by poverty and lack of institutional controls and negative human attitudes by the catchment communities has led to some practices as unsustainable waste management by industrial and domestic entities, aggravating the current deplorable state of the Ramsar site. These include over fishing, chemical contamination through farming and bush burning, solid and liquid waste disposal from both household and industrial activities. The single most serious threat to the wetland is siltation of the lagoon and receding shorelines; evidence of dwindling lagoon size over time.

There is, therefore, the need for some of interventions in the immediate future as institutional responses to the pressures and impact, to forestall and maintain the ecological sanctity of the wetland. A priority for conservation initiatives undertaken for the Sakumo Ramsar site should be to ensure the prevalence of law and order regulating the use of resources in order to maintain the ecological integrity, natural beauty and rich biodiversity of the area. This could be achieved through the education of, and awareness creation among the inhabitants of 'Sakumo anya' (i.e. people living around the fringes of the lagoon) by, governmental agencies and non-governmental organizations, about the importance of conservation to the wetland ecosystem and their own socio-economic well-being. To this end, the annual 'World Wetland Day' should be well-planned and celebrated to create the necessary awareness for the conservation of this important ecological resource.

The paper further recommends conservation initiatives to be focused on the young and middle-aged generation particularly, the fishermen in the area (aged between 20 and 45 years), since most activities that impact on the lagoon are largely undertaken by these target groups. The enforcement of the legislation by the Fisheries Department regarding the mesh sizes acceptable for fishing nets used in the lagoon should also be given priority.

The provision of proper sewage disposal facilities and treatment plants for the communities inhabiting the catchment area of the Sakumo Lagoon should be 
given prominent attention. The manufacturing activities of the three major alcoholic beverage and Textile industries, namely; Coca-cola, Kasapreko and Printex Textiles Companies, located within the basin should be controlled by the environmental protection agency (EPA), to better treat their effluents before discharging into the lagoon.

The Tema Metropolitan Assembly (TMA), Water Resources Commission (WRS) and Environmental Protection Agency should reinforce the demarcated buffer zone for the Ramsar Site and prevent encroachment particularly by estate developers. Violators should also be severely punished to serve as deterrent for others.

Obviously, the state of the lagoon warrants further research on the epidemiology and pathogenicity of the Lagoon water in relation to pollutant sources and uses of the lagoon.

\section{Acknowledgement}

The authors are very thankful to Peter Yankson of Dampong Pharmaceuticals Company, Tema, Ghana for supporting this research financially. Mr. Adu Ofori of Water Research Institute of the Council for Scientific and Industrial Research (CSIR) and Mr. Lamptey, an Engineer, at the Ashaiman Municipal Assembly need special mention for their encouragement, countless support and assistance in diverse ways which enabled the authors undertake this work. The authors finally acknowledge with thanks the office space and facilities of the Department of Geography and Rural Development, of the Kwame Nkrumah University of Science and Technology, Kumasi, put at their disposal.

\section{References}

Agyepong, G.T., Biney, C.A., Amankwah, C.C., Olesu-adjei ,I. ,and DeGraft-Johnson, K.A.A.,(1999). Management of the Sakumo Ramsar Site. Report for the Ghana Coastal wetlands Management Project. Wildlife Department, Ghana, pp. 45.

APHA-AWWA-WEF (American Public Health Association-American Water Works Association-Water Environment Federation.,(1989). Standard methods for the examination of Water and Waste water, (17th Ed.), Washington DC.

Asmah, R., Dankwa, H., Biney, C.A., and Amankwah,C.C., (2008). Trends Analysis relating to Pollution in Sakumo Lagoon, Ghana. Africa Journal of Aquatic Science, Vol.33, No.1, pp87-93.
Attuquayefio, D.K., and Gbogbo, F., (2001). Prospects of Conserving Wetlands along the Mukwe Lagoon at Nungua in the Greater Accra Region of Ghana, West African Journal of Applied Ecology, WAJAE, Vol. 2, pp. 65.

Atupra, D.K., (1993). Preliminary Studies on Some aspects of Ecology of Sakumo II Lagoon. Council for Scientific and Industrial Research-Water Research Institute, Annual Report, pp.31.

Biney, C.A.,(1995). Environmental Baseline StudiesLimnology of Sakumo II Lagoon. Ghana Coastal Wetl ands Management Project, pp. 34.

Birdlife International.,(2009). Important Bird Area factsheet: Sakumo Lagoon Ramsar Site, Ghana. Data Zone, http://www.birdlife.org (Accessed on 19/10/2009).

Entsua-Mensah, M., Ofori-Danson, P.K. ,and Koranteng, K.A., (2000). Management Issues for the Sustainable Use of Lagoon Fish Resources, pp.24-27. In Abban, E.K., Casal, C.M.V., Falk, T.M., and Pullin, R.S.V (eds.) Biodiversity and Sustainable Use of Fish in the Coastal Zone. ICLARM Conference Proceedings, PP.63, 71 .

Ghana Statistical Services., (2002). The 2000 Population and Housing Census; Special Report on Urban Localities. The Ghana Statistical Services, pp.151.

Gordon, N. D., McMahon,T. A., and Finlayson, B.L.,(1992). Stream Hydrology: An Introduction for Ecologists. John Wiley and Sons, West Sussex, England, pp. 166.

Holmbeck-Pelham, S.A., Rasmussen, T.C., and Fowler, L.A. ,(2000). Regulation of Injected Ground Water Tracers. Groundwater, Vol.38, No.4, pp.541-549.

http://sedac.ciesin.org/entri/texts/ramsar.wetlands.wate rfowl.habitat.1971.html (Accessed on 17/2/2010)

Kristensen, E., and Alongi, D.M.,(2006). Control by Fiddler crabs (Uca vocans) and Plant Roots (Avicennia marina) on carbon, iron, and sulfur biogeochemistry in mangrove sediment. Limnology E Oceanography, Vol. 51 No. 4,pp.1557-1571.

Lin T., Xue X. \& Lu C. (2007). Analysis of Coastal Wetland Changes Using the "DPSIR" Model: A Case Study in Xiamen, China. Coastal Management, Vol. 35, pp.289-303.

Martin, D.F., (1970). Marine Chemistry1. Marcel Dekker, New York, pp. 281. 
Ministry of Lands and Forestry., (1999). Managing Ghana's Wetlands: A National Wetlands Conservation Strategy, pp.4-5.

Mula-moottil, G., Warner, G. B., and Mc Bean, E.A.,(1994). Wetlands; Environmental Gradients, Boundaries, and Buffers. Lewis Publishers, London.

Ntiamoah-Baidu, Y., (1991). Conservation of coastal Lagoons in Ghana: the Traditional Approach. Landscape and Urban Plainning, Vol 20, pp.41-46.

Pirrone, N., Trombino, G., Cinnirela, S., Algieri, A.,Bendoricchio, G., and Palmeri, L., (2005). The Driver-State-State-Impact-Response (DPSIR) Approach for integrated Catchment-Coastal zone Management: Preliminary Application to the Catchment-Adriatic Sea coastal zone system, Regional Environmental Change, Vol. 5,pp.111-137.

Ramsar Convention on Wetlands., (1971). Convention on Wetlands of International Importance, Especially As Waterfowl Habitat(Ramsar), 1971.
Smeets, E. and Weterings, R., (1999). Environmental Indicators: Typology and Overview. European Environment Agency, Copenhagen. http:// reports.eea.europa.eu/TEC25/en. (Accessed on 19/10/2009).

Taebi, A. ,and Droste, R.L., (2004). Pollution loads in Urban Runoff and Sanitary Wastewater. Science of the Total Environment, Vol.327, pp.175-184.

Tumbulto, J. and Bannerman, R., (1995). Hydrology: Sakumo Ramsar Site. Environmental Baseline Studies for the Coastal Wetlands Management Project. Unpublished Report, Ghana Wildlife Department, Accra, Ghana, pp.36.

Zacharias, I., Parasidoy, A., Bergmeier, E., Kehayias, G., Dimitriou, E. and Dimopoulos, P.,(2008). A DPSIR Model for Mediterranean Temporary Ponds: European, National and Local Scale comparisons. Annals of Limnology, International Journal of Limnology Vol. 44, No. 4, pp. 253-266. 